\title{
The Function of the Constitutional Court of Albania in Exercising Control of Constitutionality Over Administrative Acts
}

\begin{abstract}
Aida Hoxhaj
Ph.D. candidate, Faculty of Law, University of Tirana aid.hoxha@gmail.com

Doi:10.5901/ajis.2014.v3n3p17

Abstract

This paper aims to analyze the process of constitutional review over normative acts, distinctive aspects of constitutional control under article 131/c of Albanian Constitution and exceptional constitutional provisions to exercise control over individual administrative acts. The selection of cases from the jurisprudence of the Constitutional Court of Albania, aims to introduce constitutional standards, requirements, criteria and features of constitutional review over administrative acts, as well as the evolution of constitutional jurisprudence. The jurisdiction of the Constitutional Court to review administrative acts in terms of abstract control of constitutionality extends only to acts of normative nature. Acts of individual nature exceptionally are subject of concrete control in terms of constitutionality and legality depending strongly in the modality of control under a particular constitutional provision. Until the system of administrative court was established, the judicial review of legality of normative acts and other acts that are not under the competence of the Constitutional Court was unclear and ineffective. The Administrative Court Act and the competence granted to the Administrative Court of Appeal to review legality of normative acts, create the possibility of judicial review in terms of abstract control of all normative acts (some exceptions are provided either by the constitution itself or by law) thus avoids ambiguity in ordinary courts practice and allows the control of the legality of normative acts that are not under the jurisdiction of the Constitutional Court. The questions addressed in this paper subject of analysis are: What are the criteria and methods of constitutional review over normative acts? What is the difference and limits of constitutional review of normative acts versus individual administrative acts? What are the features of constitutional review over acts of individual nature? What is the distinction between the control over unconstitutional normative acts and the control exercised by Administrative Court of Appeal over illegal normative acts?
\end{abstract}

\section{Constitutional Court's Jurisdiction}

Constitution as the fundamental law of the state obliges all public organs to exercise their authority only within and on the basis of constitutional provisions (Constitutional Court decision No. 16/2007). The Constitutional Court of the Republic of Albania ensures the supremacy of the Constitution within the legal system as well as constitutional justice by deciding whether the laws and other legal acts adopted by the Parliament are in conformity with the Constitution. The principle of the state under the rule of law conferred in the Constitution presupposes the hierarchy of legal acts. Under Article 116 of the Constitution, the relationships between legal norms are based on the ratio of their overlapping / subjugation (Constitutional Court decision no. 6/2012).

Constitution of Republic of Albania has vested the Constitutional Court with competencies to ensure and to safeguard the constitutional order. Constitutional jurisdiction comprises the constitutional issues that are crucial to the constitutional democracy. The jurisdiction of Constitutional Court is not general, the article 131 of the Constitution defines the core competencies of the Constitutional Court without being exhaustive. Constitutional jurisdiction can only be exercised within the framework of procedurale rules. It is a requirement to guarantee the equal protection af laws, a fondamental principle of justice that is inherent in a democratic constitution oriented toward rule of law.

Competencies of the constitutional court with regard to regulatory under-legislative acts are the most significant form of controlling executive powers, esential for functionin of the rule of law. The function of the Constitutional Court to evaluate the constitutionality is of legal nature, because by interpreting the legal norm, for which there is doubt of noncompliance with the law, the court refers to the Constitution, in its values and principles (Sadushi, 2012: 74). Control over administrative acts is part of the Constitutional Court's jurisdiction, however jurisdiction under article $131 / \mathrm{c}$ of the Constitution is limited and is exercised through review of the constitutionality of sub-statutory acts of the executive power. Subject to judicial review by the Constitutional Court are not all administrative acts that derive central and local governmental bodies, but only the acts of normative nature. Sub-statutory acts of normative content may be subject of constitutional complaint, if the allegations are raised of their incompatibility with the Constitution or international treaties ratified by Parliament of RA. 
Before the entry into force of the 'Administrative Court Act', unlawful acts of normative nature, were not subject to judicial review by the ordinary courts, instead they were largely ignored based on the principle of hierarchy of legal norms. The entry into force of the 'Administrative Court Act' enabled control of normative acts for illegality under the jurisdiction of the Administrative Court of Appeal, thus the jurisdictions of the Constitutional Court and the Administrative Court of Appeal over normative administrative acts depends on causes that will arise to challenge the unconstitutionality or illegality of the act under consideration.

Normative under-legal acts of central and local government become the subject of constitutional review in cases when the Constitutional Court hears disputes related to conflicts of competencies between powers. "Judicial dispute appear in the form of 'normative' conflict, when the powers that constitutes the object of the dispute are provided in laws, as well as in the form of 'individual' conflict, when the state bodies involved in conflict of competencies enact the relevant acts pursuant to law"(Constitutional Court decision no.29/2006). The constitutional Court expresses the position of each of holders of different powers through its decisions of constitutionality of normative or individual acts and by resolving the conflicts of competencies.

In exceptional cases the Constitutional Court becomes competent to review the constitutionality of an administrative act with individual nature. Article 115 of the Constitution provides the power directly to the Constitutional Court's jurisdiction to review an individual act of administrative nature in terms of verification of its constitutionality and legality. However constitutional jurisdiction includes specific cases when the Constitutional Court may review compliance with the Constitution over administrative acts of individual nature: Subject to constitutional review under the Constitution are decisions of Parliament for removal from office of the President of the Republic (Constitution of RA, art. 90/3), the decisions of Central Electoral Commission for verification of the results of the referendum and the election of deputies (Constitution of RA, art. 131/ë) etc. Furthermore part of review are acts of individual nature, as decisions of Parliament and decrees of the President of the Republic for the dismissal of public functionaries, or decisions of High Council of Justice for the removal of judges of common courts system, which have become subject to review by the Constitutional Court only in terms of respect on standard of due process of law, under the Article 131/f of the Constitution.

\section{Features of Judicial Review of the Constitutionality of Administrative Acts}

"Legal acts of public bodies must be in conformity with the highest legal acts, both in formal and substantial terms. The rule of law obliges all public organs to exercise their authority only within and on the basis of constitutional norms." (Constitutional Court decision no. 29/2005) The Constitution in Article 131/c provides that Constitutional Court decides on the conformity of normative acts of central and local government with the Constitution and international agreements. Unlikely to the "Law on basic constitutional provisions" of 1992 (Art. 24/3), which provided the control over the inconsistency of the under-legal acts with provisions of the Constitution and laws, the Constitution of 1998 has limited review over administrative acts. Article 131/c provides only the judicial review of the compliance of normative under-legal acts with the Constitution [and international treaties] and does not provide the judicial review of their inconsistency with laws. In exercise of the power to control sub-statutory acts under Article 131/c, the Constitutional Court performs only constitutional control of abstract nature over administrative acts of normative nature.

The Albanian legislation classifies two types of administrative acts, individual and normative (Administrative Courts Act, Art. 2). These acts regulate two distinguished levels of legal relations of public bodies having distinct procedures, factual mechanisms and special features. The difference between individual and normative acts is based on features of normative acts "they are general and addressed to an indefinite number of persons" (Constitutional Court decision nr.185/ 2001). The 'Administrative Courts Act' provides additional features in determining the characteristics of normative legal acts: "they serve as a legal basis for the issuance of individual acts, establishing general rules and behavior and are not exhaustive on implementation" -intended not for onetime application but establishing a rule of repeated conduct (Administrative Courts Act, art 2/3). The above provision gives two other distinguishing features between acts: (i) normative acts do not fail with a single application, and (ii) the act is not necessarily of normative nature when referring to an indefinite group of individuals if the act is exhausted by onetime application.

On the other hand the jurisprudence of the Constitutional Court has defined three criteria to determine the individual or normative nature of administrative act: "(i) subjects - to which the act is addressed (ii) object of the act - if it establishes a rule of conduct of abstract nature and provides compulsory rules of general nature; (iii) character exhaustive / non-exhaustive - the effects are extended to defined subjects on onetime application, or to indefinite group of individuals and situations, thus having indefinite application." (Constitutional Court decision no. 14/2014)

Although the constitutional provision $131 / \mathrm{c}$ is general, not all normative legal acts of central bodies may be subject to review by the Constitutional Court. Organs of central executive power are not only subordinated to the Prime Minister 
or the Minister, as defined by law, but also other organs that are not part of the 'classic' executive, but can be considered central for the purposes of Article 131/c of Constitution. (Toska, 2013: 286). Panel of Judges of the Constitutional Court, refused to review an administrative decision of normative nature of the Council of the School of Magistrate stating that: "The Panel of Judges finds that the act required to be subject to review by the Constitutional Court, although is a act of normative nature, is not included in the above kinds of normative acts for which this Court has jurisdiction. The Constitutional Court has no jurisdiction to review this petition."(Decision of Constitutional Court College no.30/2012)

Subjects that are entitled to apply to Constitutional Court for abstract review of normative administrative acts, are those provided by article 134/1 of the Constitution. The first four subjects: the President of the Republic, Prime Minister, not less than one-fifth of the deputies and the Chairman of the Supreme State Control, are qualified legitimate petitioners to initiate constitutional review. While other legal entities Ombudsman, local government, religious communities, political parties and other organizations explicitly have to demonstrate legal interest as a condition for filing of the petition and address to Constitutional Court for reviewing the conformity of normative administrative acts with constitution.(Constitution of RA, art. 134/2)

The subject matter of the content of a petition concerning the constitutionality of a normative administrative act under article 131/c is always the application to review whether the contested normative administrative act is compatible with the Constitution and international treaties. The grounding of a petition to review the constitutionality of normative administrative acts, consists of raising legal arguments concerning Constitutional claims on: (i) if there is a violation of the constitutional provisions by the normative act, (ii) if there is a violation of the constitutional principles (iii) if there is a violation of human rights or fundamental freedoms by the normative administrative act. The petition can be rejected if missing legal arguments that establish the basis for the doubt in normative administrative act under consideration, which substantiate the declaration of normative administrative act unconstitutional.

Normative under-legislative acts issued by the executive authorities should be in accordance with the Constitution and higher legal acts formally and substantially. "The substantial shortcomings are related to the content of the act, while formal shortcomings are associated with the procedure by which the act is adopted" (Constitutional Court decision no. 9/2010).

When hearing a case concerning the constitutionality of normative administrative act, the Constitutional Court must review if the procedure of adoption and publishing of the act complies with Article 117 of the Constitution. In the cases where it is established that a normative administrative act is not published in the manner set by the constitution or the law, or does not have legal effect, the case concerning the review of constitutionality of the legal act in question must be terminated and the Constitutional Court would consider that this case cannot be heard in the court because there is no object of the case hearing (Constitutional Court decision no. 47/1999). Ineffective legal norms are not part of hierarchical legal system. The Constitutional Court has stated that pursuant to the Constitution it has no power to examine the conformity with the Constitution of legal acts that have not come into force yet or when a contested normative legal act is deprived of its effect (Constitutional Court decision no.3/2010).

Component of the review of the constitutionality of normative legal acts are substantive elements comprising violations of the constitutional provisions and principles by the normative act, and the infringement of the fundamental rights and freedoms provided in the Constitution. Substantive judicial review also includes the requirements that the normative administrative act must be brought in respect to criteria of article 118 of the Constitution which guide and constrain the normative acting power of state organs. The Constitutional Court review consists on the control of the conformity of the normative administrative acts with the requirements on the conditions of constitutionality: (i) Statutory acts are issued on the basis of and for the implementation of the laws by the organs provided in the constitution; (ii) the law shall authorize the issuance of sub-statutory acts, (iii) designate the competent organ, (iv) the issues that are to be regulated and the principles on the basis of which the statutory acts are issued; and (v) the compliance with the terms of the delegation. (Constitution of RA, Art.118)

The practice of the Constitutional Court consists in cases of review that consider mostly the compliance of the normative administrative acts with the Stabilization and Association Agreement, the provisions of the European Union legislation and decisions of the European Court of Justice. (Constitutional Court decision No. 14/2014)

Under article 113 of Constitution, bodies of local government units adopt administrative acts of normative nature. Constitutional provisions directly define the nature of administrative acts and types of acts under jurisdiction of local government bodies. The organs of local government units issue ordinances, decisions and orders (Constitution of RA, Art.113/2), and the types of acts that are of normative nature, are subject to constitutional review for compliance with the Constitution and international agreements (Constitution of RA, Art. 131 / c).

Subjects entitled to apply for abstract review of the constitutionality have three-year term limit to approach the Court to initiate constitutional review over normative administrative acts. Under the law "On Organization and Functioning 
of the Constitutional Court" (Art. 76/1), when the Court declares a normative act unconstitutional, can only invalidate the acts it reviews. A normative administrative act the court has declared unconstitutional will be eliminated from the legal system and could not be applied to other subjects of legal relations. The decision of the Constitutional Court causes the abolition of other administrative acts implemented in compliance to invalidated sub-statutory act.

The jurisprudence of the Constitutional Court of Albania establishes that the grounds for refusal to the petition or grounds of termination of the case are:(a) subject who applies to the court is not entitled to abstract review concerning the control of the constitutionality of normative administrative act;(b) the legal act which is to be reviewed is not a normative administrative act;(c) the normative administrative act is not valid because it was not published in the manner set by the constitution or the laws; the contested normative administrative act is annulled. On the other hand, in cases when the petition for abstract review of constitutionality, legal arguments forming the basis for the doubt in normative administrative legal act under consideration are missing or considered unfounded by the Constitutional Court, the issue cannot be raised again in the future.

\section{Review of Normative Acts Haveing the Force of Law}

The competence of the Council of Ministers, provided by Article 101 of the Constitution is different from executive competencies. Only in cases of necessity and emergency the Council of Ministers may adopt normative acts having the force of law for taking temporary measures. The exceptional legal competency is limited to the extent allowed by the Constitution. Government decisions in this case are formal laws with the same value with the acts adopted by the Parliament. These acts must be approved by Parliament within 45 days, otherwise they lose force retroactively.

The Constitutional Court has jurisdiction to review the normative act with the force of law as it is 'law' in substantive terms and under Article 116 of the Constitution and therefore it is one of the acts referred to in Article 131 of the Constitution within the constitutional jurisdiction. "Control over compliance with the Constitution of the act with the force of law also extends to the law that adopted the act, in reference to Article 131 /a of the Constitution." (Constitutional Court decision No. 5/2014). The review of the constitutionality over normative acts having force of law includes the control in cases there is doubt the executive exceeds the powers provided by Article 101 of the Constitution. The Constitutional Court also reviews the compliance of normative act with the force of law with the Constitution and international agreements (Constitution of RA, art.124/1; art. 131/a; art 131/c). "If the act is not adopted or not submitted to the Parliament within 45 days, will not bring effects in the future, but at the same time, loses power from the beginning" (Constitutional Court Decision No.24/ 2006).

\section{Review Over Jurisdictional Disputes between Powers}

The Constitutional Court has competence to decide on jurisdictional disputes between the powers under article 131/ç of the Constitution, but the dispute should be related to the exercise of their power. Resolving the conflicts of competencies between powers as provided in Constitution, entitles the Constitutional Court to assess any kind of legal act or other acts of administrative nature, acting and omissions of local government units or central government organs that have caused conflict of competencies between them (Law "On the organization and functioning of the Constitutional Court of RA", Art. 54/4)

The Constitutional Court reviews the jurisdictional disputes in cases where the state bodies involved in conflict have considered themselves competent to decide on certain issues (Law On the organization and functioning of the Constitutional Court of RA, art. 54/2). To initiate review over competence's dispute can serve any kind of law or administrative act, acting or omission of government organs that has caused disagreement between powers. Constitutional Court judgment focus primarily "on the resolution of conflict of competences with regard to the constitutional level functions, finding and qualifying incompatible with the Constitution the determinative cause that has given rise to the dispute". "Every jurisdictional body, either as institution or government organ, in classic administrative terms, or as the subject who performs functions in position of full independence guaranteed by the Constitution, is considered to be a legitimate subject to the dispute of competences". (Constitutional Court Decision no. 20/2007)

The dispute of powers may appear as conflict between legal norms when the competency which constitutes the object of the dispute is provided in laws, as well as conflict between under-legislative acts, when institutions involved in conflict enact relevant acts in implementing the concrete law. In these cases, the Constitutional Court has resolved the dispute by reviewing the constitutionality and legality of the sub-statutory acts (Law On the organization and functioning of the Constitutional Court of RA, art.56). The time limits to file a petition to the Constitutional Court over the normative act that causes the jurisdictional dispute is within six-months (Law On the organization and functioning of the Constitutional 
Court of RA, art. 55), but the period of time is related to the beginning of the conflict, not to the time of entry into force of the law or administrative act in question as source of conflict of competences (Constitutional Court decision no.29/2006).

\section{Decision of the Council of Ministers over Dissolving or Discharging the Organ of Elected Local Government Unit}

A directly elected organ of a local government unit may be dissolved or discharged by the council of Ministers for serious violations of the Constitution or the laws. (Constitution of RA, art 115/1) "The decision issued by the Council of Ministers for dissolving or discharging of a local government body is an act of individual nature, because it is a decision directed to a certain organ and related to concrete issues. Constitutional Court reviews the constitutionality of the individual administrative act in question if the elected local government organ dissolved or discharged presents an appeal. The date for starting the 15-day appeal period on the individual act will be considered the date when the person is aware of the existence of the act, regardless of other forms of publication" (Constitutional Court decision nr.15/2009).

Constitutional Court's jurisdiction under article 115 of the Constitution includes in addition to assessing the constitutionality of the decision in question as well the control of legality. According to the jurisprudence of the Constitutional Court, the features of constitutional review over the decision of the Council of Ministers - in this case an administrative act of individual nature - are: "it is a judgment considering the merits of the petition, because the Constitution provides that directly elected local government unit may be dissolved or discharged from the Council of Ministers for serious violation of the law or the Constitution. Constitutional Court, as the controlling body to evaluate serious violation of the law or the Constitution, cannot do otherwise but to investigate and judge the underlying issue on merits, as a court of ordinary judicial system would act." (Constitutional Court, decision No. 22/2008)

\section{Decrees of the President of the Republic}

President of the Republic issues decrees in exercise of his powers (Constitution of RA, art. 93) that are individual acts. "The President issues decrees of political nature, which are considered acts of executive power, and other acts of appointment or dismissal of other public officials as provided in special laws, those acts are considered of administrative nature"(Sadushi, 2004: 87). According to the "98 Constitution the President of the Republic is provided with an authorization, that exceptionally in cases of war may issue decrees- acts having the force of law (Constitution of RA, art. 176), but decrees of President are generally acts of individual nature and as such cannot be subject to constitutional review (Constitutional Court decision no.25/2002)

President's decrees of administrative nature are the subject of review by the Constitutional Court if the legal arguments are raised for violation of the right to due process of law. Decrees in cases of appointments and dismissals of public functionaries, according to the Constitutional Court, are acts of administrative and constitutional nature, since they include parliamentary procedure and decisions of political nature (Constitutional Court decisions no. 2/2008). The Constitutional Court in these cases does not examine the constitutionality of the decree, but only procedural issues concerning the petition. After exhaustion of the complaint to the ordinary courts, decrees of the President of the Republic are under the jurisdiction of the Constitutional Court to control and ensure the respect of the constitutional rights to due process of law.

\section{Decisions of the Parliament}

Besides legislative activity the constitution provides Parliament with several other important functions, i.e. in cases of appointment and dismissal of the President of the Republic, the Attorney General, etc., functions that are implemented through the promulgation of decisions. Parliament approves declarations and resolutions which are acts of legal-political nature. Statements and resolutions are primarily acts of political-declarative nature, while decisions resemble somewhat administrative acts and to some extent with laws (Toska, 2013: 20). Being individual acts that do not provide compulsory rules of general nature they possess typical features of administrative legal acts and refer to a concrete fact and particular circumstances. Parliament's decisions in several cases were subject to judicial review by the Constitutional Court mainly as object of disputes between the powers. In other cases decisions of parliament are challenged for respect of the due process of law (respect of constitutional principles and procedures) during the procedures for the appointment or dismissal of high public functionaries.

Regulation of Parliament is another form of administrative act that in general cannot be subject to judicial review of constitutionality by the Constitutional Court. In specific cases may be subject to constitutional review only constitutional 
level articles reflected on Regulation, which are applied in the case under consideration, if incompatible with the Constitution (Constitutional Court Decision no. 29/2009).

\section{Decisions of the Central Election Commission}

Since its creation the Constitutional Court had jurisdiction of the review of constitutionality over the electoral process and referendums. Under article 131/e of Constitution Constitutional Court decides on issues related to the eligibility and incompabilities in exercising the functions of the deputies of Parliament (related to art.69 and art.70/3 of the Constitution), as well as the verification of their elections. The range of control by the Constitutional Court in exercising the jurisdiction over "verification of election of Members of Parliament" has been different depending on the modifications that have been made in the Electoral Code over years. Due to the adoption of fundamental changes in the Electoral Code of 2000 regarding the ways to administrate the electoral process, it was decided the right to direct appeal against the decision of the Central Election Commission to the Constitutional Court. Furthermore the Electoral Code provided judicial review by Constitutional Court of the final results of parliamentary elections ("Election Code of RA" 2000). During the election in 2001, the Constitutional Court's jurisprudence is filled with cases of review of illegality the decision of the Central Electoral Commission. The procedures followed in constitutional judgment resemble the judgment of the first instance court. Subjects addressed petitions to the Constitutional Court mainly to seek invalidation of the election - power that the Electoral Code explicitly gave to the Constitutional Court. Clearly there was a collision of legal norms between provisions of the Electoral Code of 2001 and the Law "On the organization and functioning of the Constitutional Court".

Changes brought by the Electoral Code of 2008 moved the Constitutional Court from the role that had been assigned by previous electoral codes and prevented the court from exercising the authority provided in article 131/e of the Constitution. The new code provides the 'Electoral College' within the Court of Appeals in Tirana, as the competent court to hear appeals against decisions of the Central Electoral Commission. Those substantial changes may be interpreted that the Constitutional Court has no opportunity to review the elections in the future, yet the official interpretation by the Constitutional Court of the ways to exercise the power under art.131/e remains to be seen by course of its jurisprudence in future cases.

The Constitutional Court is not confined to deal with legality issues when conducting control for verifying the results of the referendum (Constitution of RA, art. 131/h). If the Constitutional Court finds that the entire referendum process is seriously harmed, which could bring its influence on the final outcome, it decides to invalidate the decision of the Central Electoral Commission, declaring incompatible with the Constitution (Sadushi, 2012: 188).

\section{Administrative Acts Issued by the High Council of Justice}

Legal acts issued by High Council of Justice as the proposal to appoint or the decision to dismiss judges of the court of first instance and the court of appeals, or the decisions over disciplinary responsibility etc., have substantive and procedural fetures of administrative acts. Those acts are subject to review by the Constitutional Court under the article 131/f of the Constitution to final adjudication of the complaints of individual rights for the violation of their constitutional rights to due process of law after all legal remedies for the protection of those rights have been exhausted (Constitutional Court decision no.17/2004).

\section{The Competence of Administrative Court of Appels to Review Legality of Normative Administrative Acts}

Constitutional justice along with administrative justice and procedures reviewing the constitutionality and legality of normative administrative acts, constitute a uniform system of judicial review to protect the hierarchy of norms and the rule of law. Defining the limits of judicial review between the Constitutional Court and administrative courts is a delicate issue of concentrated continental model of constitutional review.

According to the doctrine of administrative law, the administrative act may be subject to conflicts of objective and subjective nature. In case of objective disputes, the administrative act is considered in view of compliance with the Constitution, international treaties and laws, meanwhile in case of subjective disputes are in consideration the subjective rights of the individuals as the subject of the dispute arising from specific substantial administrative legal relation. When the object of the review is legality of a normative administrative act, the court decides on the compatibility of the alleged unlawful act with a legal act of superior power. Review of the legality of normative acts is granted to the Administrative Court of Appeal having original jurisdiction (acting as court of first instance).

According to the law "On Administrative Courts" when the Court considers the legality of the contested normative 
legal act, will evaluate the following criteria: (i) if the choice is made by a public body in accordance with the objective and purpose of the law; (ii) if the choice of a public body is made only to achieve the purpose of law, (iii) if the choice of a public body is in proportion with the need that has dictated the size. As long as there isn't jurisprudence of the Administrative Court regarding the control of the legality of normative legal act, comparative analysis to the constitutional review exercised by the Constitutional Court can be made only on the constitutional and legal provisions that define them. Functions of the Administrative Court in reviewing the legality of normative administrative acts are analogous to functions of constitutional law in terms of the formal control (formal shortcomings) regarding the procedure by which the act is issued / approved and the reasons for refusal considered in request for review of the legality of normative administrative act.

The decisions of the Administrative Court of Appeals that abrogates or declares invalidity of the normative administrative act has 'inter partes' effect. A normative administrative act that the Administrative Court of Appeals has declared unlawful could not be applied only in certain case however the administrative act in question was not eliminated from the legal system. While Constitutional Court's decision produces a different legal effect, they are final, have general binding force and affect not only the parties to the dispute and some other persons but also all public bodies and legal entities, known as 'erga omnes' effect, and can only invalidate the acts its reviews(constitution of RA, art.132). Furthermore Constitutional Court's decisions have the power to eliminate unconstitutional normative administrative acts from the legal system.

The Administrative Court of Appeals has not had an opportunity, so far to address the issue of control of the legality of normative acts, therefore to understand the difference between substantial control of constitutionality and legality of normative legal acts, in addition to the provisions that define criteria of review must be seen the future practice of the court to draw conclusions of the issue of limits to jurisdictions, since it is clear that the causes of illegality of normative administrative acts are not only those defined to be challenge in court by the 'Administrative Courts Act'.

\section{Conclusion}

1. In the jurisprudence of the Constitutional Court is no clear stance on judicial review of the constitutionality of normative administrative acts of independent executive bodies. The jurisdiction for the control of the constitutionality is not granted for all kinds of acts.

2. Despite the fact that the competencies of the Constitutional Court do not include the control over the individual administrative acts (some exceptions are provided by constitution), it seems that there is no obstacle for Constitutional Court to decide over individual administrative acts on finale adjudication of complaints of individuals (the public functionaries), for violation of constitutional rights to due process of law.

3. Functioning of administrative courts and granting the authority to review the legality of normative acts by Administrative Court of Appeals will avoid ambiguities in previous practices in the ordinary courts on review of illegal normative administrative acts.

4. The control of formal components of legality will be identical as components of constitutionality. As far as can be seen, the Administrative Court of Appeals has not had an opportunity, so far to address the issue of control of the legality of normative acts, so the issue of control of substantial components and limits of jurisdictions, as well as differences between jurisdiction of the Constitutional Court and the Administrative Court, yet remains to the future practice of the courts to decide.

\section{References}

Kushtetuta e RSH 1998

Kodi i Procedurave Administrative të RSh

"Kodi Zgjedhor i RSh" 2000

Ligji nr. 8577, datë 10.02.2000 "Për organizimin dhe funksionimin e Gjykatës Kushtetuese të Republikës së Shqipërisë"

Vendime të Gjykatës Kushtetuese të RSh Nr. 47/1999; 25/2002; 185/2001; 17/2004; 29/2005; 24/2006; 29/2006; 16/2007; 20/2007; 2/2008; 22/2008; 15/2009; 29/2009; 3/2010; 9/2010; 6/2012; 30/2012 k; 5/2014; 14/2014

Anastasi, A., "E drejta kushtetuese", Tiranë, 2004

Dobjani, E.; Toska, E.; Puto E; Dobjani, E., "E drejta Administrative. Kontrolli mbi aministratën Publike", Tiranë, 2013

Sadushi, S., "Drejtësia Kushtetuese në Zhvillim", Tiranë, 2012

Sadushi, S., "E drejta Administrative 2", Tiranë, 2005

Sadushi, S., "Kontrolli Kushtetues", Tiranë, 2004

Toska, E., "Kontrolli mbi veprimtarinë administrative sipas praktikës së Gjykatës Kushtetuese të Shqipërisë", Tiranë, 2013 